This article was downloaded by: [Monash University Library]

On: 05 February 2015, At: 03:51

Publisher: Routledge

Informa Ltd Registered in England and Wales Registered Number: 1072954

Registered office: Mortimer House, 37-41 Mortimer Street, London W1T

3J H, UK

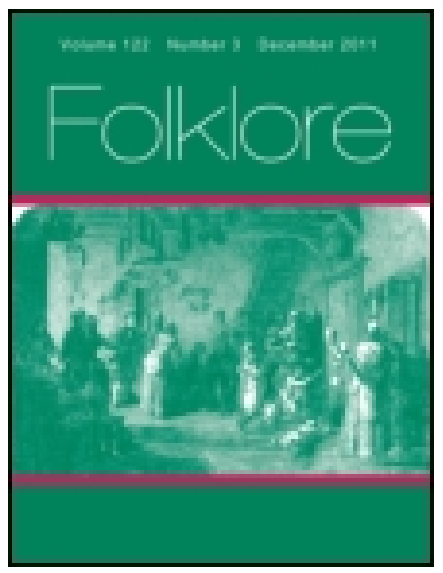

\title{
Folklore
}

Publication details, including instructions for authors and subscription information:

http:// www.tandfonline.com/loi/ rfol20

\section{First-Footing in Scotland}

G. Hastie

Published online: 14 Feb 2012.

To cite this article: G. Hastie (1893) First-Footing in Scotland, Folklore, 4:3, 309-314, DOI: $10.1080 / 0015587 X .1893 .9720166$

To link to this article: http:// dx. doi. org/ 10.1080/0015587X.1893.9720166

\section{PLEASE SCROLL DOWN FOR ARTICLE}

Taylor \& Francis makes every effort to ensure the accuracy of all the information (the "Content") contained in the publications on our platform. However, Taylor \& Francis, our agents, and our licensors make no representations or warranties whatsoever as to the accuracy, completeness, or suitability for any purpose of the Content. Any opinions and views expressed in this publication are the opinions and views of the authors, and are not the views of or endorsed by Taylor \& Francis. The accuracy of the Content should not be relied upon and should be independently verified with primary sources of information. Taylor and Francis shall not be liable for any losses, actions, claims, proceedings, demands, costs, expenses, damages, and other liabilities whatsoever or howsoever caused arising directly or indirectly in connection with, in relation to or arising out of the use of the Content.

This article may be used for research, teaching, and private study purposes. Any substantial or systematic reproduction, redistribution, reselling, loan, sub-licensing, systematic supply, or distribution in any form to anyone is 
expressly forbidden. Terms $\&$ Conditions of access and use can be found at http://www.tandfonline.com/page/terms-and-conditions 
FIRST-FOOTING IN SCOTLAND.

FIRST-FOOTING is enacted with great glee and vivacity $F$ in various parts of Scotland, but more especially so in Edinburgh. The origin of this nocturnal visit and welcome, and subsequent merrymaking, arose from marriage customs, mostly in Galloway and Wigtonshires, where marriages were generally celebrated on New Year's Day. About a century ago the young maidens of the district, who might be courting, would, on the approach of New Year's Eve, in a coaxing kind of a way, invite their sweethearts and companions to be their first-foot on New Year's morning; of course the hint was always readily accepted, and generally ending in due course by marriage on a subsequent New Year's Day; and even at the present time the custom is still kept up of domestic servants (and especially so in Edinburgh) inviting their sweethearts to be their first-foot-for good luck, and, if need be, for marriage. A dark-complexioned young man was always considered lucky, and a likely suitor. The mode and hour of visit of the first-foot was, as near as possible, just after midnight, and in some instances parties of young people would visit the favoured ones, and sometimes quite a carousal took place, drinking, eating, singing, and dancing, and sometimes ending in a fight between the jealous rivals, and thus breaking up the merry gathering.

The mode of visit, as I have said, was just after midnight. The family visited, of course, expected someone to be their first-foot, and had preparations made accordingly, in the shape of refreshments, and in some instances the household were aroused out of bed. In others the daughter or daughters were prepared for the nocturnal visitor or visitors, and thus the first-footer was not kept waiting 
outside for his welcome; storms being considered of no account on such occasions, but rather added to the glee.

The first-foot, on crossing the threshold, at once announced "A gude New Year to ane and a', and mony may ye see," or "A happy New Year tae ye, and God's blessing"; then kissing the young woman, and shaking her by both hands, they passed into the household. If the visitor had not been seen for some time, the news of the families were gone into, and other matters of that sort ; then the whiskydrinking, with health-giving toasts, eating of shortbread, currant loaf, scones, oat-cakes, and cheese were all heartily consumed, then song-singing, sometimes a dance, then more drinking, and at last came the parting, in much hilarity and glee, the "toozling" (or hugging) and kissing of the young woman or women, and then off went the nocturnal visitor or visitors for other calls, until daylight appearing stopped their fun; or else the first-footers kept on making their calls, drinking and carousing all through New Year's Day, and even on, far on, New Year's Night, when, possibly, they were worn out, and utterly prostrated with fatigue and want of sleep. Of course the first-footing only strengthened the courtship, the regular visiting continuing, and generally ending in marriage on a subsequent New Year's Day.

In "Auld Reekie", the custom of first-footing ("firstfittin", in Scotch) dates from time immemorial ; generally, the preparations for the midnight orgies of New Year's Eve begin to show themselves in the early part of the evening in the stir and bustle of the leading thoroughfares of the city; groups of young men moving listlessly about, as evidently wearying for the fun to begin. The church of the Tron Men, or labourers of the city. has long been the gathering-place or rendezvous of the first-footers. Some sixty or seventy years ago, firstfooting in Edinburgh required ingenuity and courage on the part of young men who went first-footing from the Tron Church, owing to the danger and rioting and fighting 
amongst the first-footers ; the whisky-shops, as they were then called, being open all night (and any amount of whisky to be had cheap, very cheap, say one shilling and twopence, or one shilling and threepence per bottle of five gills, and very good then), enabled the revellers to keep up. continued supplies in their bottles. Then there were the "Baxters", or "Batchies Bow wow wows" (as they were termed then, bakers), and who were known by their peculiar trade-signal or whistle (and who were a powerful body of men, requiring great strength of neck and head to. carry, say, forty or forty-five loaves on a large board or tray, placed on the head); they, leaving off their work, would sally forth into the streets, and join in the revelry. Then the students attending the University would likewise turn in and join the crowds, and if perchance a wrong expression or slighting word crept from one of the students. towards a "batchie", then woe betide all : bottles and glasses. were smashed, blows were exchanged freely, a regular mélée occurring, and everyone fleeing his or her own way out of the shindy, until the row dwindled down or was. fought out, leaving many a cut and scar to be accounted for.

This mode of procedure of first-footing is as followed now in Edinburgh. The Anglican element is slowly but surely invading Scotland at this period in Edinburgh; it begins about the first of December in the display of Christmas. cards in shop-windows and on the counters of our leading. dry-goods shops. Then on comes Christmas Day, which in the New Town principal shops make an afternoon holiday of it, and in some instances closed for the day. Someof the Presbyterian churches hold service, and altogether the day has an appearance of a holiday in the city. The festivities continue through the week, the schools are closed, and the people generally preparing for the great event of the year in Scotland, namely, the ushering in of New Year's Day in real earnest Scotch fashion. From the appearance of the leading thoroughfares, it is evident thereis an expectancy of something about to take place in the 
city; groups of young men and maidens move listlessly about, others coming into the city from the country districts. Then, towards evening, the thoroughfares become thronged with the youth of the city, and by ten o'clock, in the neighbourhood of the Tron Church, small crowds of young men begin to gather, and to grow impatient for the midnight hour of carousal, first-footing, and general welcoming in of the New Year, say 1893 . Next, as the midnight hour approaches, drinking of healths becomes frequent, and some are already intoxicated; the crowds become denser, the police are moving actively about regulating the traffic, which is fast becoming congested at this point, namely, the North and South Bridge Streets crossing the High Street at the "Tron". The publichouses are now closed, it is past eleven o'clock, the streets have become darker, the crowds very dense, and the hum of the voices louder and louder, when suddenly a great coloured light appears from some elevated point in the High Street. One after another of these coloured lights continue, then the bells or tubes of bronze of St. Giles now begin to ring for the midnight service, when, altogether, the scene is one of a most awe-inspiring nature. The eyes of the immense crowd are ever being turned towards the lighted clock-face of the "Auld and Faithfu" Tron, the hour approaches, the hands seem to stand still, but in one second more the hurrahing, the cheering, the hand-shaking, the health-drinking, the swaying to and fro of the immense throng, is all kept up as long as the clock continues to ring out the much-longed-for midnight hour. Many a one has there met and shaken hands for the first time and the last with the stranger, never to see or meet each other again. The crowds slowly disperse, the much intoxicated and helpless ones being hustled about a good deal, the police urging them on out of harm's way. The first-footers are off and away, flying in every direction through the city, singing, cheering, and shaking hands with all and sundry; "A gude New Year and mony o" 
them"; " A happy New Year and many returns"; "A guid New Year and a' the better than the last yin"; "A gude New Year tae you and yours, and may yere meal-poke ne'er be empy" (empty), and so forth, and so forth, according as the well-wisher or first-footer has learned in his or her own local district at such a time the New Year's good wishes.

The first-footing has thus begun in real earnest throughout the city, the windows of some of the houses are all ablaze with light, and, to add zest to all, away far up on the ramparts of the grand historical pile, the Castle, stand the band of the Highland Regiment therein stationed at that time; then shaking hands and wishing each other "A gude New Year", you hear the strains of "A guid New Year in Scotia yet", "For auld lang syne", "God save the Queen", and a final round of cheers, then all is still.

The old Scotch families who keep up the old customs encourage their domestics to come in and first-foot them for good luck in their home, wishing them "a lucky gude" New Year, generally accompanied with a gift of money or dress. Then again, grandparents are pleased to have their grandchildren first-foot them, and in many, many cases this rhyme was sung or said by the children visiting the old people :

"Get up, guid wife, and shake yere feathers, An dinna think that we are beggars, For we 're yere bairns come oot the day, So rise and gie's oor Hogmonay ;"

which was accordingly done with great glee. The older children sometimes were given "ginger cordial", now called wine, with shortbread, currant loaf, scones, oat-cake, cheese, and sometimes an orange or an apple added, with of course the New Year's penny for "guid luck". This, then, was a child's first-footing to grannie. Then, in the case of the seniors, as before described, there was the nocturnal welcome, the love-making, the health-drinking, the song-sing- 
ing, the dancing, the toozling, the "pairtin" (or leave-taking), and at last the "first-fittin is ower" (is over).

Then out on the streets all is bustle and commotion, hurrying to and fro of young people, cheering and singing, some drinking and health-toasting, every possible and conceivable portable musical instrument brought into play ; cheer after cheer, chorus after chorus, rend the air of the early morn, and not until daylight sends them home do the streets of Edinburgh resume their usual wont and quiet; and thus all this stir, all this commotion, all this hubbub, over the old, old custom of "first-fittin", the first lucky foot to cross a threshold on the New Year's morn, and to be sure and not to go in "empty-handed" (without a gift), to some one, and especially the loved one, else bad or ill luck or poverty thereafter.

Since the passing of the Forbes MacKenzie Act, closing the public-houses at eleven o'clock, the increase of our police forces, the action of the Early Rechabites and total abstainers, in conjunction with temperance societies of every grade, and the evangelistic workers in all our churches, all uniting in one grand endeavour to stay the forces of the evil of intoxication at such a time as New Year, and now the inducements of recreation and amusements of every description instead, is fast bringing into. disuse and distaste the "auld, auld custom of 'first-fittin' in Guid Auld Scotia".

\section{G. HASTIE.}

[Mr. Hastie's account of First-Footing in Edinburgh is valuable as giving the actual experience of an old resident of the town, and has therefore been left untouched.-ED. F..L.] 